\title{
PENGARUH GAYA BELAJAR SISWA DAN PERGAULAN TEMAN SEBAYA TERHADAP PRESTASI BELAJAR SISWA PADA MATA PELAJARAN IPS KELAS VIII DI SMP NEGERI 1 MUNDU KABUPATEN CIREBON
}

\author{
Asep Saefudin ${ }^{1}$, Yeti Nurizzati ${ }^{2}$ \\ IAIN Syekh Nurjati Cirebon ${ }^{1,2}$ \\ saefudinasep157@gmail.com; yeti@syekhnurjati.ac.id
}

\begin{abstract}
Abstrak
Berdasarkan hasil observasi siswa kesulitan menyesuaikan gaya belajar mereka dengan cara mengajar guru. Serta ada pergaulan siswa yang senang ke perpustakaan, dan adasiswa yanghanya bermain dan bercanda sehingga berdampak pada prestasi belajar. Penelitian ini bertujuan untuk mengetahui seberapa besar pengaruh gaya belajar siswa dan pergaulan teman sebaya terhadap prestasi belajar siswa pada mata pelajaran IPS kelas VIII di SMP Negeri 1 Mundu Kabupaten Cirebon. Pengaruh gaya belajar terhadap prestasi belajar merupakan kunciuntuk mengembangkan kinerja dalam sekolah. Pengaruh pergaulan teman sebaya terhadap prestasi belajar adalah ketika siswa bersama teman-teman melakukan aktivitas yang bermanfaat maka bisa mendapatkan prestasi terbaik. Penelitain ini merupakan penelitian kuantitatif ex post facto. Populasi penelitian ini sebanyak 277 siswa. Sampel peneliti sebanyak 56 siswa. Teknik pengambilan sampel menggunakan simple random sampling. Teknik pengumpulan datanya menggunakan observasi, angket dan dokumentasi. Adapun analisis data yang digunakan adalah analisis prosentase, uji normalitas, uji linearitas, uji multikolinearits, uji heteroskedastisitas, dan uji regresi linier berganda. Hasil penelitian diperoleh persamaan regresi linier bergada $Y=102,240+0,276 X_{1}$ -

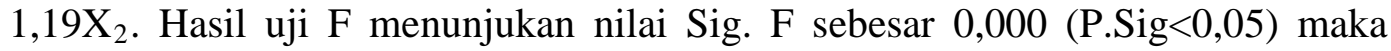
dapat disimpulkan terdapat pengaruh gaya belajar dan pergaulan teman sebaya berpengaruh terhadap prestasi belajar. Nilai koefisien determinasi sebesar 29,4\%.Sedangkan sisanya 70,6\% dipengaruhi oleh variabel lain.
\end{abstract}

Kata Kunci: Gaya Belajar, Pergaulan Teman Sebaya, Prestasi Belajar.

\begin{abstract}
Based on the results of observation students have difficulty adjusting their learning style by teaching the teacher. And there are associations of students who love to the library, and there are students who just play and joke so that the impact on learning achievement. This study aims to determine how big the influence of student learning styles and association of peers against student achievement on subjects IPS class VIII in SMP Negeri 1 Mundu Kabupaten Cirebon. The influence of learning styles on learning achievement is key to improving school performance. The influence of peers association to learning achievement is when students with friends doing activities that are useful then can
\end{abstract}


get the best performance. This research is an ex post facto quantitative research. The population of this study were 277 students. The sample of researchers are 56 students. The sampling technique using simple random sampling. Data collection techniques use observation, questionnaires and documentation. The data analysis used is percentage analysis, normality test, linearity test, multicolinearits test, heteroscedasticity test, and multiple linear regression test. The result of the research shows linear regression equation $Y=102,240+0,276 X 1-1,19 X 2$. The result of F test shows Sig value. F of 0.000 (P.Sig <0,05) it can be concluded that there is influence of learning style and association of peers influence on learning achievement. The coefficient of determination was 29.4\%. While the remaining $70.6 \%$ influenced by other variables.

\section{Keywords: Learning Style, Peer Friendship, Learning Achievement.}

\section{A. PENDAHULUAN}

1. Latar Belakang Masalah

Pendidikan nasional berfungsi mengembangkan kemampuan dan membentuk watak serta peradaban bangsa yang bermartabat dalam rangka mencerdaskan kehidupan bangsa, bertujuan untuk berkembangnya potensi peserta didik agar menjadi manusia yang beriman dan bertakwa kepada Tuhan Yang Maha Esa, berakhlak mulia, sehat, berilmu, cakap, kreatif, mandiri, dan menjadi warga negara yang demokratis serta bertanggung jawab” (Pasal 3 UU RI No 20/ 2003). Hal tersebut menunjukan bahwa pendidikan merupakan upaya yang terencana, yang menggunakan berbagai proses dan metode tertentu dengan tujuan untuk mengembangkan potensi yang ada dalam diri peserta didik agar terjadi perubahan pengetahuan, tingkah laku dan keterampilan.

Chatib sebagaimana dikutip Suparman (2010: 63) mengatakan bahwa hakikatnya gaya mengajar yang dimiliki guru adalah strategi transfer informasi yang diberikan kepada anak didiknya, sedangkan gaya belajar adalah bagaimana sebuah informasi dapat diterima dengan baik oleh siswa. Jadi, antara gaya mengajar guru dan gaya belajar siswa adalah dua hal yang sangat berkaitan, saling mendukung satu sama lain, dan sangat menentukan keberhasilan suatu proses belajar mengajar. Guna memudahkan dalam memilih gaya mengajar, maka ada baiknya guru mengetahui perihal gaya belajar siswa. Setiap siswa memiliki gaya belajar yang berbeda. 
Kemampuan kognitif, kecepatan dalam menerima dan mengolah informasi yang dimiliki siswa perlu dirangsang melalui tampilan yang bervariasi agar informasi yang diterima dapat diolah dengan berbagai indera. Siswa diharapkan akan dapat menerima dan menyerap dengan mudah pesan-pesan dalam materi yang disajikan.

Menurut Horton dan Hunt dalam Dasmar (2011: 74) kelompok teman sebaya (peer grup) merupakan suatu kelompok dari orang-orang yang seusia dan memiliki status yang sama, dengan siapa seseorang umumnya berhubungan atau bergaul. Sedangkan menurut Heslin dalam Damsar (2011: 75) mengemukakan bahwa kelompok teman sebaya memiliki daya paksa terhadap orang yang masuk kedalamnya. Hampir tidak mungkin orang melawan kelompok teman sebaya yang peraturan utamanya "konfirmasi atau penolakan”. Seseorang yang tidak melakukan apa yang dilakukan orang lain "menjadi orang luar”, "bukan anggota”, "kasta luar”.

Menurut Surya dalam Priansa (2016: 43) prestasi belajar adalah perubahan perilaku individu sehingga peserta didik akan memperoleh perilaku yang baru, menetap, fungsional, positif, didasari, dan sebagainya. Perubahan perilaku sebagai hasil pembelajaran atau prestasi belajar adalah perilaku secara keseluruhan yang mencakup aspek kognitif, afektif, konatif, dan motorik.

Berdasarkan hasil observasi yang dilakukan di SMP Negeri 1 Mundu Kabupaten Cirebon bahwa peneliti mendapati siswa yang mengalami kesulitan atau lamban dalam menangkap pelajaran IPS, Siswa juga kerap kesulitan menyesuaikan cara atau gaya belajar mereka dengan cara mengajar guru di sekolah. Maka ini menandakan bahwa siswa memiliki karakteristik yang berbeda, memiliki cara menerima pelajaran yang berbeda-beda di kelas. Hal tersebut berdampak pada rendahnya prestasi belajar siswa yang terlihat dari nilai UTS.

Selain gaya belajar, faktor lain yang mempengaruhi prestasi belajar adalah pergaulan teman sebaya sebagaimana yang dikatakan Ibu Tuti Agustina sebagai guru IPS kelas VIII ada dua pola pergaulan diantara siswa misalnya: yang pertama kelompok siswa yang berprestasi dan kedua 
kelompok siswa yang suka melanggar aturan sekolah. kelompok siswa yang berprestasi lebih senang menghaskan waktunya dengan membaca buku dan pergi ke perpustakaan. Lain halnya dengan kelompok yang enggan mengikuti aturan sekolah dan guru mereka lebih banyak menghabiskan waktunya di luar kegiatan yang berhubungan dengan kegiatan sekolah atau belajar, mereka lebih banyak waktu bermainya dari pada belajar. Hal inilah yang membuat peneliti tertarik untuk membahasnya, sehingga mengangkat judul yaitu:“Pengaruh Gaya Belajar Siswa dan Pergaulan Teman Sebaya terhadap Prestasi Belajar Siswa pada Mata Pelajaran IPS Kelas VIII di SMP Negeri 1 Mundu Kabupaten Cirebon”.

\section{Rumusan Masalah}

Berdasarkan latar belakang masalah di atas, maka masalah dalam penelitian ini dapat dirumuskan sebagai berikut:

a. Bagaimana gaya belajar siswa dan pergaulan teman sebaya kelas VIII di SMP Negeri 1 Mundu Kabupaten Cirebon?

b. Bagaimana prestasi belajar siswa kelas VIII di SMP Negeri 1 Mundu Kabupaten Cirebon?

c. Seberapa besar pengaruh gaya belajar siswa dan pergaulan teman sebaya terhadap prestasi belajar siswa pada mata pelajaran IPS kelas VIII di SMP Negeri 1 Mundu Kabupaten Cirebon?

3. Tujuan Penelitian

Berdasarkan permasalahan yang ada maka tujuan penelitian ini adalah sebagai berikut:

a. Untuk mengetahui gaya belajar siswa dan pergaulan teman sebaya kelas VIII di SMP Negeri 1 Mundu.

b. Untuk mengetahui prestasi belajar siswa kelas VIII di SMP Negeri 1 Mundu.

c. Untuk mengetahui seberapa besar pengaruh gaya belajar siswa dan pergaulan teman sebaya terhadap prestasi belajar siswa pada mata pelajaran IPS kelas VIII di SMP Negeri 1 Mundu. 


\section{B. KAJIAN TEORI}

1. Pengertian Belajar dan Gaya Belajar

Belajar adalah suatu aktivitas atau suatu proses untuk memperoleh pengetahuan, meningkatkan keterampilan, memperbaiki perilaku, sikap, dan mengokohkan kepribadian. Dalam konteks menjadi tahu atau proses memperoleh pengetahuan, menurut pemahaman sains konvensional, kontak manusia dengan alam diistilahkan dengan pengalaman (eksperince), pengalaman yang terjadi berulang kali melahirkan pengetahuan, (knowledge), atau a body of knowledge (Heriyano danSuryono, 2012: 9).

Menurut DePorter dan Hernacki dalam Dirman dan Juarsih, (2014: 99) gaya belajar siswa adalah kombinasi dari bagaimana ia menyerap dan kemudian mengatur serta mengolah informasi. Gaya belajar peserta didik dapat dikelompokan ke dalam tiga gaya belajar, yaitu: gaya belajar visual, gaya belajar auditif, dan gaya belajar kinestetik. Adanya pengkategorian gaya belajar tersebut ini tidak berarti bahwa peserta didik hanya memiliki salah satu karakteristik cara belajar tertentu saja sehingga tidak memiliki karakteristik cara belajar yang lain. Pengkategorian ini merupakan panduan bahwa peserta didik memiliki kecenderungan kepada yang paling menonjol kepada salah satu di antara gaya belajar tersebut.

2. Pengertian Teman Sebaya

Santrock (2007: 55) mendefinisikan teman sebaya ialah anak-anak atau remaja yang memiliki usia atau tingkat kematangan yang kurang lebih sama yang saling berinterakasi dengan kawan-kawan sebaya yang berusia sama dan memiliki peran yang unik dalam budaya atau kebiasaannya. Sedangkan menurut Horton dan Hunt dalam Damsar (2011: 74) menyatakan bahwa yang dimaksud dengan kelompok teman sebaya (peer group) adalah suatu kelompok dari orang orang yang seusia dan memiliki status sama, dengan siapa seseorang umumnya berhubungan atau bergaul.

3. Pengertian Prestasi Belajar

Djamarah (2012: 28), menyebutkan bahwa prestasi belajar dapat dikatakan sebagai kebutuhan yang menimbulkan dorongan dari dalam diri 
siswa untuk terus belajar. Sedangkan menurut Purwanto dalam Priansa (2016: 44) menyatakan bahwa prestasi belajar adalah perubahan perilaku peserta didik yang terjadi setelah mengikuti proses belajar mengajar sesuai dengan tujuan pendidikan.

4. Kajian Penelitian Relevan

Penelitian yang dilakukan oleh Nastiti Dyah Lutfita (2014) dengan judul "Pengaruh Gaya Belajar Siswa terhadap Prestasi Belajar Matematika di Smp Negeri 1 Ngunut”.

a. Persamaan penelitian

Persamaan penelitian sekarang dengan penelitian dari Nastiti Dyah Lutfita (2014) yaitu sama-sama menggunakan penelitian kuantitatif.Persamaan lainnya terletak pada variabel independent dan dependent dimana variabel independent yaitu gaya belajar dan variabel dependent yaitu prestasi belajar.

b. Perbedaan peneilitian

Perbedaan penelitian sekarang dengan penelitian Nasiti Dyah Lutfita (2014) terletak pada variabel independent, dimana pada penelitian terdahulu menggunakan satu variabel independen yakni gaya belajar, sedangkan pada penelitian sekarang menggunakan dua variabel independent yakni gaya belajar Siswa dan pergaulan teman sebaya.

\section{METODE PENELITIAN}

1. Jenis Penelitian

Penelitian ini termasuk penelitian kuantitatif, ex post facto artinya penelitian tentang variabel yang kejadiannya sudah terjadi sebelum penelitian dilaksanakan (Arikunto 2011: 17).

2. Lokasi Dan Waktu Penelitian

Penelitian dilakukan di SMP Negeri 1 Mundu Kabupaten Cirebon. Adapun waktu pelaksanaan penelitian dari bulan Desember 2017 - Februari 2018. 
3. Populasi dan Sampel

a. Populasi

Populasi dalam penelitian ini adalah seluruh siswa kelas VIII SMP Negeri 1 Mundu Kabupaten Cirebon tahun pelajaran 2017/2018 yang terdiri dari 8 kelas dengan jumlah 277siswa.

b. Sampel

Jumlah sampel yang akan digunakan penulis yaitu 20\% dari seluruh kelas VIII. Maka diambil 20\% jadi sebanyak 55,4 dibulatkan menjadi 56 siswa yang menjadi sampelnya, dengan perhitungan $: \frac{20}{100} \times 277=$ $55,4=56$.

4. Variabel Penelitian

Variabel independen dalam penelitian ini adalah gaya belajar dan pergaulan teman sebaya. Sedangkan variabel dependen dalam penelitian ini adalah prestasi belajar siswa.

5. Teknik danInstrumen Pengumpulan Data

a. Observasi

Observasi pada penelitian ini dilakukan untuk mengetahui kondisi real gaya belajar siswa di dalam kelas dan mengetahui kondisi real pergaulan teman sebaya di tempat penelitian.

b. Angket

Pembuatan butir-butir soal angket terdiri dari 40 Pernyataan untuk variabel (X) dan untuk variabel (Y) 14 pernyataan. Dalam hal ini peneliti menggunakan skala likert.

c. Dokumentasi

Metode dokumentasi ini dimaksudkan untuk memperoleh datamengenai jumlah siswa, gambaran umum SMP Negeri 1 Mundu Kabupaten Cirebon dan data prestasi belajar nilai UTS semester satu, tahun ajaran 2016/2017 mata pelajaran Ilmu Pengetahuan Sosial. 
6. Validitas dan Reliabilitas Instrumen

a. Uji Validitas

Uji validitas adalah suatu uji keabsahan instrument penelitian yang akan digunakan untuk pengumpulan data yang berkaitan dengan variabel penelitian.

b. Uji Reliabilitas

Reliabilitas menunjuk pada satu pengertian bahwa sesuatu instrument cukup dapat dipercaya untuk digunakan sabagai alat pengumpul data karena instrument tersebut sudah baik (Arikunto, 2011: 221).

7. Teknik Analisis Data

a. Uji Porsentase

Pengumpulan data yang dilakukan dalam uji prosentase ini yaitu dengan menyebarkan angket kepada siswa yang sudah menjadi sample penelitian (Sugiyono, 2009: 183).

b. Uji Normalitas

Uji normalitas bertujuan "menguji apakah dalam sebuah model regresi, variabel dependent, variabel independent atau keduannya mempunyai distribusi normal, atau tidak”. Model regresi dikatakan baik apabila distribusinya normal atau mendekati normal (Ghozali 2011:160).

c. Uji Linearitas

Uji linearitas bertujuan untuk mengetahui apakah dua variabel mempunyai hubungan yang linear secara signifikan atau tidak. Data yang baik seharusnya terdapat hubungan yang linear antara variabel predictor (X) dengan variabel kriterium (Y) (Sutrisno 2004: 13).

d. Uji Multikolinearitas

Multikolinearitas berarti adanya hubungan yang pasti, diantara beberapa atau semua variabel yang menjelaskan dari model regresi. Uji Multikolinearitas dimaksudkan untuk menguji apakah terdapat hubungan variabel yang sempurna diantara variabel independent atau semua variabel dari model regresi (Ghozali 2011:175). 
e. Uji Heteroskedastisitas

Heteroskedastisitas adalah suatu keadaan dimana masing-masing kesalahan atau residu yang mempunyai varian yang berbeda dan dimaksudkan untuk menguji apakah varian dari kesalahan pengganggu tidak konstan untuk semua variabel bebas. Model regresi yang baik adalah jika tidak terjadi heteroskedastisitas (Sugiyono 2009: 161).

f. Uji Regresi Linier Berganda

Menurut Irianto (2004: 193) Regresi linier berganda sederhana adalah regresi linier dimana sebuah variabel terikat (variabel $\mathrm{Y}$ ) dihubungkan dengan dua atau lebih variabel bebas (variabel X).

g. Uji Hipotesis t dan F

Uji t untuk mengetahui pengaruh antara variabel bebas terhadap variabel terikat secara parsial.

Uji F untuk mengetahui pengaruh secara bersama-sama atau simultan antara variabel bebas dengan variabel terikat.

\section{HASIL PENELITIAN DAN PEMBAHASAN}

Penelitian ini dilakukan untuk mengetahui seberapa besar pengaruh gaya belajar siswa dan pergaulan teman sebaya terhadap prestasi belajar siswa di SMP Negeri 1 Mundu Kabupaten Cirebon. Telah dilakukan selama tiga bulan sekaligus dalam analisis serta penulisan, banyak berbagai informasi yang didapat oleh peneliti. Adapun dalam pembahasan mengenai penelitian ini adalah terdapat pengaruh yang signifikan pada gaya belajar siswa dan pergaulan teman sebaya terhadap prestasi belajar siswa pada mata pelajaran IPS.Dari hasil penelitian yang diuji, diketahui gaya belajar dari 56 siswa. kelas VIII sebagian besar memiliki gaya belajar visual. Terbukti dari hasil angket yang menjawab sangat setuju kebanyakan menjawab di pernyataan gaya belajar visual.Dari hasil penyebaran angket variabel mengenai gaya belajar $\left(\mathrm{X}_{1}\right)$ di dapat hasil rata-rata yaitu $65,3 \%$ untuk pernyataan positif , hasil angket ini berada pada rentang 61\% - 80\% sehingga tergolong pada kategori baik. Dan untuk pernyataan negatif didapat hasil rata-rata 36,1\% pada rentang 21\% - 40\% sehingga tergolong pada kategori kurang baik. 
Gaya belajar yang dimiliki oleh setiap siswa merupakan salah satu kunci dalam mencapai prestasi belajar. Perbedaan gaya belajar dari setiap siswa menunjukkan kecenderungan cara bagi mereka dalam memahami dan menyerap informasi. Dan dalam hasil observasi yang dilakukan diketahui bahwa cara mengajar guru di kelas VIII SMP Negeri 1 Mundu hanya menggunakan metode ceramah sehingga gaya belajar siswa dapat mempengaruhi prestasi belajar siswa. Hal ini diperkuat oleh DePorter danHernacki (2002: 112) yang mengemukakan bahwa "gaya belajar adalah kunci untuk mengembangkan kinerja dalam pekerjaan, sekolah, dan dalam situasi antar pribadi. Dengan begitu, gaya belajar mempengengaruhi peserta didik dalam menyerap dan mengolah informasi yang akan berpengaruh pada pencapaian prestasi peserta didik”.

Dari hasil penelitian yang diuji, diketahui pergaulan teman sebaya dari 56 siswa yang dijadikan sampel yaitu pada kelas VIII SMP Negeri 1 Mundu memiliki pergaulan teman sebaya yang hampir seluruhnya memiliki keakraban yang tinggi. Terbukti dari hasil angket bahwa hampir seluruhnya siswa mengatakan sangat setuju dan setuju pada pernyataan keakraban dalam indikator pergaulan teman sebaya. Hasil penyebaran angket mengenai pergaulan teman sebaya $\left(\mathrm{X}_{2}\right)$ pada pernyataan positif didapat hasil rata-rata yaitu $86,6 \%$ hail angket ini berada pada rentang 81\% - 100\% sehingga tergolong baik sekali. Dan untuk pernyataan negatif didapat hasil rata-rata 69,8\% hasil angket ini berada pada rentang 61\% - 80\% sehingga tergolong pada kategori baik.

Pergaulan teman sebaya siswa kelas VIII di SMP Negeri 1 Mundu cenderung mengarah ke hal yang negatif karena dalam pengamatan siswa cenderung berkumpul hanya untuk bermain, bergurau dan sebagainya. Waktu istirahat tidak digunakan untuk belajar kelompok, atau pergi ke perpustakaan, hal itu menyebabkan pergaulan teman sebaya berpengaruh terhadap prestasi belajar siswa. Selain itu menurut Asher dan Wentzel dalamJohn W. Santrock (2007: 533) mengatakan bahwa siswa yang lebih diterima oleh teman sebayanya dalam hal hubungan pertemanan dan mempunyai keahlian sosial 
yang baik sering kali lebih bagus prestasinya di sekolah serta mempunyai motivasi akademik yang positif.

Hasil dokumentasi untuk melihat prestasi belajar siswa peneliti mengambil nilai uts semester pertama yang menunjukkan bahwa prestasi belajar siswa mata pelajaran IPS pada kelas VIII SMP Negeri 1 Mundu sebanyak 25 siswa $(44,6 \%)$ memiliki prestasi belajar dengan nilai $\geq 75$ yang berarti mencapai kriteria ketuntasan minimal (KKM) yang telah ditentukkan disekolah, sedangkan sisanya 31 siswa (55,4\%) mendapat prestai belajar $\leq 75$ dan termasuk dalam kategori belum tuntas. Data nilai yang peneliti dapatkan menunjukkan bahwa prestai belajar IPS siswa kelas VIII SMP Negeri 1 Mundu masih kurang optimal.

Dengan hasil persamaan regresi linier berganda diketahui nilai koefisien $X_{1}$ sebesar 0,276, koefisien tersebut bernilai positif artinya terjadi hubungan positif antara gaya belajar dengan prestasi belajar maka semakin naik gaya belajar maka semakin meningkat prestasi belajar. Sehingga dapat disimpulkan bahwa jika nilai gaya belajar $\left(\mathrm{X}_{1}\right)$ meningkat 1 satuan maka nilai prestasi belajar (Y) akan meningkat sebesar 0,276 dengan asumsi nilai $\mathrm{X}_{2}$ tetap. Koefisien $\mathrm{X}_{2}$ sebesar -1,193, koefisien tersebut bernilai negatif artinya terjadi hubungan negatif antara pergaulan teman sebaya dengan prestasi belajar siswa, maka semakin naik pergaulan teman sebaya maka semakin menurun prestasi belajar.

Hipotesis yang diterima sesuai dengan uji t diketahui nilai Sig untuk variabel gaya belajar sebesar 0,003 (P.Sig<0,05) maka Ha diterima dan H0 ditolak, dengan kata lain gaya belajar siswa berpengaruh terhadap prestasi belajar siswa pada mata pelajaran IPS kelas VIII di SMP Negeri 1 Mundu Kabupaten Cirebon. Dan untuk variabel pergaulan teman sebayabahwa nilai Sig sebesar 0,001 (P.Sig<0,05) maka Ha diterima H0 ditolak, dengan kata lain pergaulan teman sebaya berpengaruh terhadap prestasi belajar siswa pada mata pelajaran IPS kelas VIII di SMP Negeri 1 Mundu Kabupaten Cirebon.Berdasarkan hasil uji f menunjukan bahwa nilai Sig. F sebesar 0,000 (P.Sig<0,05) maka dapat disimpulkan bahwa H0 ditolak, dengan kata lain gaya belajar siswa dan pergaulan teman sebaya berpengaruh terhadap prestasi 
belajar siswa pada mata pelajaran IPS kelas VIII di SMP Negeri 1 Mundu Kabupaten Cirebon.

Selanjutnya untuk mengetahui besarnya kontribusi atau sejauh mana sumbangan variabel independent terhadap variabel dependent. Maka bisa dilihat dari tabel Model Summary. Dan diketahui hasil koefisien determinasi di atas terdapat R Square $\left(\mathrm{r}^{2}\right)$ sebesar 0,294 nilai tersebut untuk menyatakan besar kecilnya sumbangan variabel gaya belajar dan pergaulan teman sebaya terhadap prestasi belajar ditentukan dengan mencari koefisien determinasi (KP) yaitu $\mathrm{KP}=\mathrm{R}^{2}$ x $100 \%=29,4 \%$. Artinya variabel gaya belajar dan pergaulan teman sebaya memberikan kontribusi terhadap variasi prestasi belajar sebesar 29,4\% dan sisanya 70,6\% dijelaskan oleh variabel lain.

\section{E. KESIMPULAN DAN SARAN}

1. Kesimpulan

Berdasarkan hasil penelitian yang peneliti lakukan, maka dapat disimpulkan data dan uraian sebagai berikut :

a. Gaya belajar siswa yang terdapat pada kelas VIII di SMP Negeri 1 Mundu sebagian besar memiliki gaya belajar visual. Terbukti dari hasil angket bahwa sebagian besar siswa menyatakan sangat setuju pada pernyataan gaya belajar visual.

b. Pergaulan teman sebaya yang terdapat pada kelas VIII di SMP Negeri 1 Mundu Kabupaten Cirebon memiliki pergaulan teman sebaya yang hampir seluruhnya memiliki keakraban yang tinggi. Terbukti dari hasil angket bahwa hampir seluruhnya siswa mengatakan sangat setuju dan setuju pada pernyataan keakraban dalam indikator pergaulan teman sebaya.

c. Prestasi belajar siswa pada mata pelajaran IPS kelas VIII di SMP Negeri 1 Mundu Kabupaten Cirebon, dari total 56 sampel sebanyak 25 siswa $(44,6 \%)$ memiliki prestasi belajar dengan nilai $\geq 75$ yang berarti mencapai kriteria ketuntasan minimal (KKM) yang telah ditentukkan disekolah, sedangkan sisanya 31 siswa (55,4\%) mendapat prestai belajar $\leq 75$ dan termasuk dalam kategori belum tuntas. Data nilai yang 
peneliti dapatkan menunjukkan bahwa prestai belajar IPS siswa kelas VIII SMP Negeri 1 Mundu Kabupaten masih kurang optimal.

d. Dengan hasil persamaan regresi linier berganda diketahui nilai koefisien X1 sebesar 0,276, koefisien tersebut bernilai positif artinya terjadi hubungan positif antara gaya belajar dengan prestasi belajar maka semakin naik gaya belajar maka semakin meningkat prestasi belajar. Sehingga dapat disimpulkan bahwa jika nilai gaya belajar (X1) meningkat 1 satuan maka nilai prestasi belajar (Y) akan meningkat sebesar 0,276 dengan asumsi nilai X2 tetap. Koefisien X2 sebesar 1,193, koefisien tersebut bernilai negatif artinya terjadi hubungan negatif antara pergaulan teman sebaya dengan prestasi belajar siswa, maka semakin naik pergaulan teman sebaya maka semakin menurun prestasi belajar. jika pergaulan teman sebaya (X2) meningkat 1 satuan maka nilai prestasi belajar (Y) akan menurun sebesar 1,193 dengan asumsi nilai X1 tetap.

2. Saran

a. Bagi guru Ekonomi, guru dituntut untuk menggunakan berbagai metode pembelajaran sehingga mampu mengkoordinir tiap-tiap gaya belajar yang dimiliki siswanya. Selain itu guru diharapkan dapat memanfaatkan interaksi sosial yang terjadi dalam pergaulan kelompok teman sebaya guna memotivasi siswa dalam belajar sebagai upaya peningkatan prestasi belajar.

b. Bagi siswa, siswa perlu mengenali gaya belajar yang dimiliki dan mengoptimalkan gaya belajarnya sehingga mampu menemukan metode belajar yang sesuai dengan diri siswa. Dan siswa juga diharapkan lebih selektif dalam memilih teman bergaul dan menciptakan lingkungan pergaulan kelompok teman sebaya yang baik dengan mendukung teman-teman dalam kegiatan sekolah.

c. Bagi sekolah, Agar prestasi balajar IPS meningkat, sekolah diharapkan dapat memfasilitasi siswa untuk dapat mengenal karakteristik belajar dan dominasi gaya belajar yang dimilikinya. Penting juga bagi sekolah untuk memberikan kiat-kiat belajar efektif 
sesuai dengan gaya belajar yang dimiliki siswa melalui bimbingan konseling atau pelatihan pelatihan.

d. Bagi peneliti selanjutnya, Penelitian ini memberikan informasi bahwa Gaya Belajar Siswa dan Pergaulan Teman Sebaya secara bersamasama berpengaruh terhadap Prestasi Belajar IPS Siswa Kelas VIII SMP Negeri 1 Mundu Kabupaten Cirebon. Sumbangan efektif yang diberikan sebesar 29,4\%. Hal tersebut menunjukkan bahwa masih ada 70,6\% faktor lain yang dapat mempengaruhi Prestasi Belajar IPS namun tidak diteliti pada penelitian ini. Oleh karena itu, diharapkan dalam penelitian selanjutnya dapat ditemukan faktor-faktor lain yang dapat mempengaruhi Prestasi Belajar IPS.

\section{DAFTAR PUSTAKA}

Arikunto, Suharsimi. 2006. Prosedur Penelitian Suatu Pendekatan Praktik. Jakarta: Rineka Cipta.

Damsar. 2011. Pengantar Sosiologi Pendidikan. Jakarta: Kencana Prenada Media Group.

Dirman dan Juarsih. 2014. Karakteristik Peserta Didik. Jakarta: Rineka Cipta.

Djamarah, Syaiful Bahri. 2012. Strategi Belajar Mengajar. Jakarta: Rineka Cipta.

Ghozali, Imam. 2011. Aplikasi Analisis Multivariate dengan Program SPSS. Semarang: BP Universitas Diponegoro.

Heriyanto, Suyono. 2012. Belajar dan Pembelajaran. Bandung: Remaja Rosdakarya.

Irianto, Agus. 2004. Statistik (Konsep Dasar, Aplikasi, dan Pengembangannya). Jakarta: Kencana.

Lutfita, Nasiti Dyah. 2014. “Pengaruh Gaya Belajar Siswa Terhadap Prestasi Belajar Matematika Di SMP Negeri 1 Ngunut. Tulungagung: IAIN Tulungagung.

Priansa Donni. 2016. Pengembangan Strategi \& Model Pembelajaran. Bandung: Pustaka Setia. 
Santrock, John W. 2007. Perkembangan Anak, Edisi Ketujuh, Jilid Dua. (Alih bahasa: Mila Rachmawati dan Anna Kuswanti). Jakarta: Penerbit Erlangga.

Sugiyono. 2009. Metode Penelitian Pendidikan (Pendekatan Kualitatif, Kuantitatif dan $R$ \& D). Bandung: Alfabeta.

Suparman. 2010. Gaya Mengajar yang Menyenangkan Siswa. Yogyakarta: Pinus.

Sutrisno, Hadi. 2004. Analisis Regresi. Yogyakarta: Andi Offset.

Undang-undang Republik Indonesia No. 20 Th. 2003 Tentang System Pendidikan Nasional. 
